\title{
The Influence of Value-oriented Teaching upon Vital Competences Formation of 7-9 Years Old Pupils during Physical Education Lessons
}

\author{
Oleksandr Mozolev ${ }^{1}$, Maryna Khmara ${ }^{1}$, Inna Yashchuk ${ }^{2}$, Ludmila Kravchuk $^{3}$, Viktoriia Matviichuk ${ }^{3}$, \\ Andrii Kalenskyi ${ }^{4}$, Valentyna Miroshnichenko ${ }^{5,}$, Oleksandr Halus ${ }^{6}$ \\ ${ }^{1}$ Department of Theory and Methodology of Physical Culture and Valeology, Khmelnytskyi Humanitarian-Pedagogical Academy, \\ Ukraine \\ ${ }^{2}$ Department of Pedagogy, Khmelnytskyi Humanitarian-Pedagogical Academy, Ukraine \\ ${ }^{3}$ Department of Therapy, Ergotherapy, Physical Culture and Sports, Khmelnytskyi Institute of Social Technologies of University \\ "Ukraine", Ukraine \\ ${ }^{4}$ Laboratory for Scientific-methodological Support of Specialists Training in Colleges and Technical Schools, Institute of Vocation \\ Education and Training of the National Academy of Educational Sciences of Ukraine, Ukraine \\ ${ }^{5}$ Department of Pedagogics and Social-economic Disciplines, Bohdan Khmelnytskyi National Academy of the State Border Guard \\ Service of Ukraine, Ukraine \\ ${ }^{6}$ Department of Management Education, Khmelnytskyi Humanitarian-Pedagogical Academy, Ukraine
}

Received March 4, 2020; Revised April 24, 2020; Accepted May 3, 2020

Copyright $\mathrm{C} 2020$ by authors, all rights reserved. Authors agree that this article remains permanently open access under the terms of the Creative Commons Attribution License 4.0 International License

\begin{abstract}
The article deals with the problem of the influence of value-oriented teaching upon the formation of vital competences of 7-9 years old pupils during physical education lessons. Applied, short-term, descriptive research in the framework of sociological experiment has been conducted. The advantages of value-oriented teaching have been analyzed; its positive impact upon the formation of pupils' vital competences has been established. To obtain the necessary information, we used general scientific methods of theoretical level of research, namely: analysis of scientific and methodological sources, surveys, questionnaires, expert evaluation method, axiological analysis, pedagogical modeling, pedagogical experiment, pedagogical observation, methods of mathematical statistics. The research involved 294 pupils from 3 primary schools in the city of Khmelnytskyi (Ukraine) forming part of the experimental group (EG) $(\mathrm{n}=148)$ and the control group $(\mathrm{CG})-(\mathrm{n}=146)$ based on the principle of gender equality. The pupils of the experimental group followed the curriculum using the author's program "Value-Oriented Teaching of 7-9 Years Old Pupils during Physical Education Lessons", and the pupils of the control group followed the traditional system of education. The results were evaluated by the experts represented by elementary school physical education teachers $(\mathrm{n}=34)$ and parents $(\mathrm{n}=272)$ who determined the level of formation of the most important value orientations of pupils: improvement of health; independent behavior; team morale (teamship); equality;
\end{abstract}

respect; formation of new motor skills; consciousness. The research confirmed the effectiveness of the author's program. According to the experts, the increase in the formation of value orientation indicators in the experimental group compared with the control one is +6.19 points, which corresponds to $22.1 \%$, and according to the parents, it is +4.96 points, which corresponds to $17.7 \%$.

Keywords Physical Education, Value-oriented Teaching, Pupils, Author's Program, Vital Competencies

\section{Introduction}

Physical education is one of the important components of a child's development aimed at strengthening his/her health, the development of physical, moral and volitional as well as intellectual abilities for the purpose of harmonious formation of personality. The elementary-school age is the responsible period in the children development when their bodies are intensively developing, the character and outlook of the children is being formed and the basis of the general physical preparation of the personality is being laid [1].

Physical education in Ukrainian schools is a guided social and pedagogical process aimed at improving health, developing motor skills and achieving physical improvement for pupil youth [2]. The main form of 
classroom hours' organization is a lesson and it is the only form of physical education for many children that should have a positive impact upon their health and life, form values and vital motor skills and abilities, increase their physical activity and physical fitness, and prepare them for educational and daily activities $[3 ; 4]$.

Many years of experience in physical education with children of different age groups allows us to say with certainty that the negative effects associated with children's health and life will continue until the method of teaching physical education in school education changes dramatically. In our view, a new technique for organizing a physical education lesson such as the "School of Competencies" will help the teacher focus on the cyclic solution of specific scheduled tasks and enable the introduction of value-oriented exercise complexes during the lesson [5].

The main feature of the competency building approach compared to the traditional one lies in the shift of the emphasis from the accumulation of normative knowledge, skills and abilities towards the formation and development of pupils' ability to act practically, to use individual technique and experience of successful actions in situations of professional activities and social practice [6; 7]. Herewith, preference is given to such forms of lessons that create situations where each pupil can identify himself/herself in the team, has the opportunity to express himself/herself and approve himself/herself in the educational process [8].

The hypothesis of the research was the assumption that the introduction of value-oriented teaching during physical education lessons will help to form vital competences of 7-9 years old pupils, which will allow them to act effectively in personal, professional and social life situations in the future.

The purpose is to investigate the effectiveness of the author's program of physical education lessons conduct for 7-9 years old pupils, which is aimed at the formation of vital competences based on value-oriented teaching.

Tasks:

- to establish priority values of physical education lessons conduct with 7-9 years old pupils;

- to develop author's program of influence of value-oriented teaching upon vital competences formation of 7-9 years old pupils during physical education lessons;

- to check the effectiveness of the author's program of value-oriented education upon vital competences formation of elementary school pupils.

\section{Material \& Methods}

Participants: 294 7-9 years old pupils forming part of the experimental group (EG) - 148 pupils and control group (CG) - 146 pupils based on the principle of gender equality.

Organization of the research. The research work was conducted on the basis of three primary schools in the city of Khmelnytskyi between September 2019 and January 2020. We conducted applied, short-term, descriptive research in the framework of sociological experiment.

\section{Methods.}

To obtain the necessary information, we used general scientific methods of theoretical level of research, namely: analysis of scientific and methodological sources, surveys, questionnaires, expert evaluation method, axiological analysis, pedagogical modeling, pedagogical experiment, pedagogical observation, methods of mathematical statistics.

The analysis of scientific and methodological sources has been used to study the current state of scientific community views upon the problem of organizing physical education lessons with 7-9 years old pupils. Surveys and questionnaires have been conducted to determine the priority of parents' value orientations in organizing the process of physical education in elementary school. The expert evaluation method has been used to determine the priority of teachers' value orientations in organizing the process of physical education with 7-9 years old pupils. Axiological analysis has been carried out to determine the system of values to be formed in 7-9 years old children and to create their motivation towards exercising. Pedagogical modeling has been used in the development of experimental variants of the content of conducting physical education lessons taking into account previously obtained information [9]. Methods of mathematical statistics have been used to determine the level 7-9 years old pupils' vital competencies formation.

Considering the tasks of forming vital competences of 7-9 years old pupils during physical education lessons, it was necessary for us to organize the educational process based on the following values: improving the level of health, equality, respect, team morale, independent behavior, consciousness, formation of new motor skills.

To organize and implement our research, we have developed the author's program "Value-Oriented Teaching of 7-9 Years Old Pupils during Physical Education Lessons".

Objectives of the program:

- awareness of the value of health, development of active motivation to maintain and promote health, forming the ability to self-assess health, to provide self- and mutual assistance;

- ability to make decisions independently and to interact in a team;

- ability to interact constructively on the basis of tolerance;

- building knowledge, skills and abilities of safe behavior at home, school, in the street, and public places.

The pedagogical tasks were combined into three cycles during which the teacher fulfills educational, wellness and 
attitude development goals. The respective competences (social, functional, motivational) are defined for each group of tasks and the teacher selects the necessary block of scheduled material (information, operational, motivational). The structure of the lesson envisaged four obligatory parts: adaptation, search, training, summary $[10$; 11].

Since the purpose of our research is to form vital competencies based on value-oriented teaching, precisely the search and training parts of the physical education lesson envisaged a variety of tasks given to pupils that were aimed at solving problems of varying complexity based on available knowledge, the ability to perform different social roles such as leader-organizer and subordinate-executor, developing skills to work in a team.

The value-oriented educational program was implemented over 4 months and included three stages:

1. Adaptation stage (2-3 weeks). The objective of the stage is gradual preparation for systematic physical training, formation of a sustainable interest in various types of physical activities, adaptation to exercise stresses, socialization of pupils, and formation of health values. The lessons are of health improving and recreational nature.
2. Formation stage (8-9 weeks). The objective of the stage is to provide pupils with knowledge, to develop basic skills and abilities, purposeful development of priority value orientations. The lessons are of game nature.

3. Development stage (6-7 weeks). The objective of the stage is organization of pupils' independent work, practical application of the individual skills developed during team activities, creation of problematic situations that require the use of the competences formed in the course of different game and life situations. The nature of the lessons is presented through emotionally enriched educational situations.

In order to determine the level of formed value orientations offered in the author's educational program, the parents and the experts had to determine the number of points for each criterion of value orientations in accordance with the requirements of Table 1.

Evaluation of the formation of value orientations of 7-9 years old pupils during physical education lessons was determined as the average of the experts' and parents' evaluations. Both individual values and their totality were evaluated.

Table 1. Evaluation of the level of formation of value orientations

\begin{tabular}{|c|c|c|c|c|c|}
\hline \multirow[b]{2}{*}{ No. } & \multirow[b]{2}{*}{$\begin{array}{c}\text { Formation criteria of value } \\
\text { orientations }\end{array}$} & \multicolumn{4}{|c|}{ Levels of value orientations formation } \\
\hline & & $\begin{array}{l}\text { High (deep, systematic } \\
\text { knowledge; creative task } \\
\text { execution, independent } \\
\text { evaluation of situations, } \\
\text { knows how to defend } \\
\text { his/her own position) }\end{array}$ & $\begin{array}{c}\text { Sufficient } \\
\text { (applies knowledge } \\
\text { in standard situations } \\
\text { independently, draws } \\
\text { conclusions, corrects } \\
\text { mistakes) }\end{array}$ & $\begin{array}{l}\text { Intermediate } \\
\text { (performs tasks on } \\
\text { a model, has } \\
\text { elementary skills } \\
\text { of educational } \\
\text { activities) }\end{array}$ & $\begin{array}{c}\text { Initial } \\
\text { (fragmentary } \\
\text { knowledge and } \\
\text { skills, initial } \\
\text { ideas about } \\
\text { value } \\
\text { orientations) }\end{array}$ \\
\hline 1. & $\begin{array}{l}\text { Axiological (formation of value } \\
\text { orientations as vital competences) }\end{array}$ & 4 & 3 & 2 & 1 \\
\hline 2. & $\begin{array}{l}\text { Epistemological (formation of the } \\
\text { system of knowledge, skills and } \\
\text { abilities in everyday activities) }\end{array}$ & 4 & 3 & 2 & 1 \\
\hline 3. & $\begin{array}{c}\text { Emotional-volitional (manifestation } \\
\text { of psychological qualities such as } \\
\text { orderliness, discipline, duty, honor, } \\
\text { dignity) }\end{array}$ & 4 & 3 & 2 & 1 \\
\hline 4. & $\begin{array}{l}\text { Health-saving (personal hygiene, care } \\
\text { for clothing, adherence to day regimen } \\
\text { and diet, prevention of posture defects, } \\
\text { bad habits) }\end{array}$ & 4 & 3 & 2 & 1 \\
\hline 5. & $\begin{array}{l}\text { Health and fitness (increase of motion } \\
\text { activities and working capacity, } \\
\text { organism improvement and cold water } \\
\text { treatment) }\end{array}$ & 4 & 3 & 2 & 1 \\
\hline 6. & $\begin{array}{l}\text { Motivational (forming a conscious } \\
\text { attitude to physical education and } \\
\text { sports, increasing interest in the } \\
\text { lessons, engaging others in the } \\
\text { activities) }\end{array}$ & 4 & 3 & 2 & 1 \\
\hline 7. & $\begin{array}{c}\text { Activity (formation of value } \\
\text { orientations in practical activities) }\end{array}$ & 4 & 3 & 2 & 1 \\
\hline 8. & $\begin{array}{c}\text { Situational (formation of value } \\
\text { orientations in a specifically created } \\
\text { situation i.e. under certain conditions) }\end{array}$ & 4 & 3 & 2 & 1 \\
\hline
\end{tabular}




\section{Results}

In order to form value orientations of 7-9 years old pupils in physical education, we have conducted a questionnaire survey of 272 parents and 34 physical education teachers of lower grades, who were to identify the 5 most prioritized value orientations of the 12 offered and rank them according to their importance [12]. Comparative analysis of the parents' and teachers' questionnaire results is presented in (Fig. 1)

It should be noted that the value orientation of "improving health" was determined by the overwhelming majority of the respondents. Therefore, the construction of physical education of 7-9 years old children was based primarily on this value orientation. We have used sets of exercises aimed at developing and strengthening the respiratory system, musculoskeletal system and cardiovascular system to develop vital health-promoting skills. The conduct of bodily exercises, physical training breaks, psycho-regulatory and ideomotor exercises was also of great importance.

Analysis of the results of the questionnaire survey on the priority of value orientations during physical education lessons revealed differences in the views of parents and experts (teachers) upon the formation of such values as: team morale (teamship) - parents $5.6 \%$, experts $11.4 \%$; equality - parents $15.2 \%$, experts $8.0 \%$; formation of new motor skills - parents $6.4 \%$, experts $12.6 \%$; consciousness - parents $10.2 \%$, experts $7.6 \%$. Therefore, we decided not to identify 5 but 7 key value orientations for physical education, which were the most important for parents and experts, namely: improving health; independent behavior; team morale (teamship); equality; respect; formation of new motor skills; consciousness.

The experts' and parents' evaluation on the implementation of the author's program of value-oriented teaching during physical education lessons of 7-9 years old pupils in comparison with the traditional one is presented in table 2 .

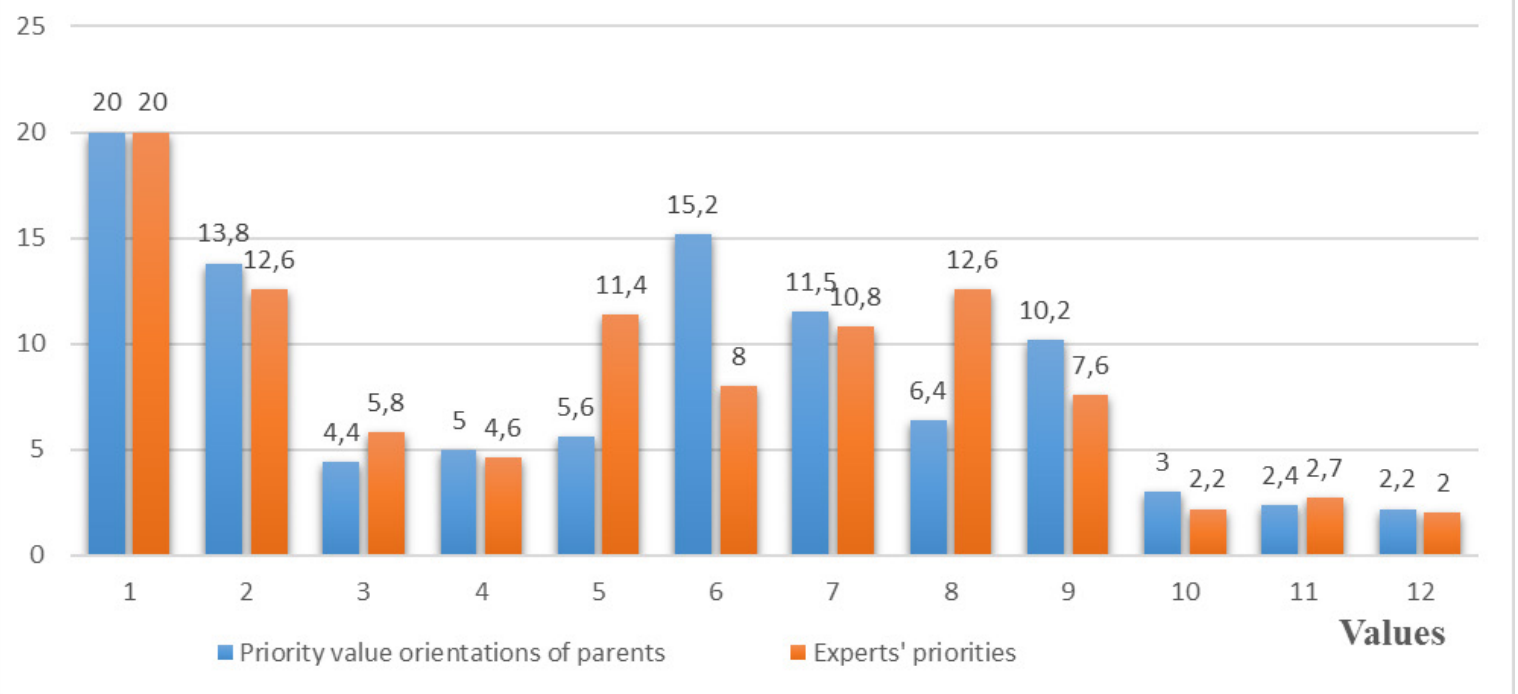

Figure 1. The distribution of physical education value orientations of 7-9 years old children and the results of the parents' and teachers' questionnaire survey, where: 1 . Improving health; 2. Independent behavior; 3. Self-esteem; 4. Motivation; 5 . Team morale (teamship); 6. Equality; 7. Respect; 8. Formation of new motor skills; 9. Consciousness; 10. Experience; 11. Formation of volitional powers; 12. Organizational abilities

Table 2. Evaluation of results of value orientations formation of 7-9 years old pupils

\begin{tabular}{|c|c|c|c|c|c|c|c|}
\hline \multirow[b]{2}{*}{ No. } & \multirow[b]{2}{*}{ Value orientations } & \multicolumn{3}{|c|}{ Experts' evaluation $(\mathrm{n}=34)$} & \multicolumn{3}{|c|}{ Parents' evaluation $(\mathrm{n}=173)$} \\
\hline & & $\begin{array}{l}\text { Experimental } \\
\text { group }\end{array}$ & $\begin{array}{l}\text { Control } \\
\text { group }\end{array}$ & Difference & $\begin{array}{l}\text { Experimental } \\
\text { group }\end{array}$ & $\begin{array}{l}\text { Control } \\
\text { group }\end{array}$ & Difference \\
\hline 1 & health improvement & 3,50 & 3,34 & $+0,16$ & 3,38 & 3,24 & $+0,14$ \\
\hline 2 & equality & 2,84 & 1,46 & $+1,38$ & 2,62 & 1,36 & $+1,26$ \\
\hline 3 & respect & 2,38 & 1,91 & $+0,47$ & 2,58 & 2,02 & $+0,56$ \\
\hline 4 & team morale (teamship) & 3,06 & 1,85 & $+1,21$ & 2,94 & 2,07 & $+0,87$ \\
\hline 5 & independent behavior & 2,55 & 2,07 & $+0,48$ & 2,77 & 2,10 & $+0,67$ \\
\hline 6 & consciousness & 2,95 & 1,73 & $+1,22$ & 3,12 & 2,23 & $+0,89$ \\
\hline 7 & formation of new motor skills & 3,14 & 1,87 & $+1,27$ & 2,93 & 2,36 & $+0,57$ \\
\hline 8 & Total points & 20,42 & 14,23 & $+6,19$ & 20,34 & 15,38 & $+4,96$ \\
\hline
\end{tabular}


The analysis of the experts' findings showed that in the experimental group, compared to the control group, such value orientations were much better formed as: equality with the rate of growth of 1.38 points; formation of new motor skills with the rate of growth of 1.27 points; consciousness with the rate of growth of 1.22 points and team morale (teamship) with the rate of growth of 1.21 points. The experts noted that the level of formation of these value orientations of pupils corresponded to the sufficient and high level in the experimental group, and these indicators were at the initial and intermediate levels in the control group. Only the health improvement rate was high.

The parents' evaluation of the author's program of value-oriented teaching during physical education lessons of 7-9 years old pupils compared to the traditional one also highlighted the benefits of the new program. According to the parents, the indicators of value-orientations development in the experimental group were much better than in the control group: equality with the rate of 1.26 points; consciousness with the rate of 0.89 points and team morale (teamship) with the rate of 0.87 points. The parents noted that the health improvement rate in both groups was high. The level of formation of other value orientations of pupils in the experimental group corresponded to the sufficient level, and, respectively, to the intermediate and sufficient level in the control group. The parents noted that the control group had the lowest level of such value orientation as "equality", which was at the initial level.

It should be noted that parents' evaluations sometimes differed significantly from experts' evaluations, which in our opinion, is attributed to the subjective view concerning the group (experimental or control) their child studied at.

The results of research of value orientation formedness, according to the experts and parents, have proved the effectiveness of the author's program "Value-Oriented Teaching of 7-9 Years Old Pupils during Physical Education Lessons". The following changes took place in the experimental group compared to the control group:

- decreased number of pupils with the initial level of value orientation formation;

- increased number of pupils with intermediate and high level of value orientations;

- increased number of pupils who are able to make their own decisions, interact in a team, use their skills creatively, tolerate one another and others;

- increased interest in exercising, own health and the factors influencing it;

- increased level of the pupils' physical activity.

\section{Discussion}

According to foreign and national experience, the results of value-oriented teaching are due to a much deeper and more conscious understanding of the essence of the studied material by the pupils, the formation of motor skills and abilities to exercise independently, to make decisions, to carry out self- and mutual evaluation, to respect alternative thoughts, to work in a team, to build constructive relations with its members and determine their place in it [13]. The ultimate aim of such education at elementary school is to provide younger pupils with vital competences $[14 ; 15]$.

The restructuring of the educational process requires the creation of fundamentally new standards for elementary education, and demands the search for new forms and methods of physical education for pupils, which should be based on value-oriented approaches to teaching and formation of vital competences [16]. Goal and value transformations for improving the content of physical education lessons in elementary school are considered by scientists in terms of:

- formation pupils' stable motivation to maintain and strengthen their health, the need for physical development [17; 18];

- use of various means to ensure harmonious development and healthy lifestyle [19];

- $\quad$ study of foreign experience of organizing physical education lessons in elementary school [20;21];

- use of various forms of school and extra-curricular work for the development of physical abilities of younger pupils $[22 ; 23 ; 24]$;

- optimization of the processes of adaptation to the conditions of learning in school $[25 ; 26]$;

- use of the latest information and communication technologies in the process of physical education [27; 28];

- change of priorities in the content and qualitative training of physical education specialists who are able to apply modern methods of conducting physical education lessons [29; 30].

Our research results analysis confirms the views of Petkova, M., Aleksieva, M.; Galan, Y., Koshura, A., Moseychuk, Y., Paliichuk, O., Moroz, O., Tsybanyuk, O., Yarmak, O. on the priority of improving the state of health and meeting the needs for motor activity of younger pupils within the system of motives for physical education in elementary school $[31 ; 32]$.

Summarizing the results of our research we have expanded:

- research data by Aksenova, O., \& Kirilenko, L. on the practical application of the methodology of competency-oriented teaching [10].

- research data by Omelyanenko, I.; Roters, T. on changing priorities and improving the scheduled basis for physical education lessons conduct in elementary school $[33 ; 34]$.

- research data by Marchenko S.; Gricyuk S. on the effectiveness of the impact of game teaching 
methods and combination training upon improving the skills of collective actions, finding the most rational ways to solve both sports and entertainment problems [29; 30].

- $\quad$ scientific views of Miroshnichenko, V., Andreeva O., Golovach I., Khripo I. on the need to develop the motivation of 7-9 years old pupils during physical education lessons, that allows to activate their individual and group activities, contributes to the formation of organizational, search and creative work [37; 38].

The proposed and substantiated author's program "Value-Oriented Teaching of 7-9 Years Old Pupils during Physical Education Lessons" included three stages: adaptation, formation and development ones. These stages are logically interconnected and complement each other from the perspective of a competency approach, have a positive effect upon the level of erudition and the formation of the pupils' vital skills, and are determined by the ability to solve problems of varying complexity based on existing knowledge and ability to use the gained knowledge. With this approach, the goals of education are transformed into new opportunities acquired by the pupils, and reflect the growth of their personal potential.

\section{Conclusions}

1. The conducted research confirmed the effectiveness of introducing value-oriented education of 7-9 years old pupils during physical education lessons, which contributes to better formation of a personality capable of successfully solving problematic situations, involves the constant engagements of pupils to active educational and cognitive activities, motivates them for leadership, creative approach and active position in all types of physical activities, involves not getting, but acquiring knowledge and skills, and as a consequence, positively influences the formation of their vital competencies.

2. The conducted research and the obtained results regarding the solution of the problem of formation of value orientations towards studying by 7-9 years old pupils during physical education lessons allow us to confirm the effectiveness of the author's program. According to the experts, the increase in the formation of indicators of value orientations offered in the program in the experimental group compared with the control one is +6.19 points, which corresponds to $22.1 \%$, and it is +4.96 points corresponding to $17.7 \%$ according to the parents' evaluation.

\section{Disclosure Statement}

No author has any financial interest or received any financial benefit from this research.

\section{Conflict of Interest}

The authors state no conflict of interest.

\section{REFERENCES}

[1] M. Burenko. Attitudes towards in physical exercises by younger students, Physical culture, sport and health of nation, Vol. 1, 21-25, 2016. [in Ukrainian].

[2] O. M. Mozolev. A management development of education is in the field of physical culture and sport in Ukraine: European measuring, Announcer of the Cherkasy university, Vol. 5, 124-130, 2018. [in Ukrainian].

[3] L. A. Gucan. Forming of the valued orientations of junior schoolboys in the conditions of modernization of the system of education, Institute of problems of education of the National academy of pedagogical sciences of Ukraine, Vol. 5, 94-100, 2017. [in Ukrainian].

[4] N. V. Moskalenko. Physical education of junior schoolboys. Dnipropetrovsk: Innovation, 2009. [in Ukrainian].

[5] O. Shkola, G. Griban, K. Prontenko, O. Fomenko, V. Zhamardiy, V. Bondarenko, S. Bezpaliy, V. Andreychuk, P. Tkachenko, Ye. Zhukovskyi, I. Novitska, I. Bloshchynskyi. Formation of valuable orientations in youth during physical training. International Journal of Applied Exercise Physiology. 8(3.1): 261-269, 2019. Doi: 10.26655/IJAEP.2019.10.1

[6] I. Burgun. The relevance of implementing a competency based approach to educational practice, Collection of scientific labours of the Kherson national technical university, Vol. 1-2, 159-165, 2010. [in Ukrainian].

[7] G. Griban, K. Prontenko, T. Yavorska, S. Bezpaliy, T. Bublei, M. Marushchak, L. Pustoliakova, V. Andreychuk, P. Tkachenko., Ye. Zhukovskyi, A. Baldetskiy, I. Bloshchynskyi. Non-traditional means of physical training in middle school physical education classes. International Journal of Applied Exercise Physiology. 8(3.1): 221-229, 2019. Doi: 10.26655/IJAEP.2019.10.1

[8] S. Bulavenko. Formation of value orientations as a basis of social activity of students, Young people and market, Vol. 3(170), 114-119, 2019. [in Ukrainian].

[9] O. Mozolev. Pedagogical Projecting of the Model of a Future Specialist. Pedagogical Discourse, Vol. 24, 82-87, 2018. DOI: 10.31475/ped.dys.2018.24.12

[10] O. P. Aksenova, L. V. Kirilenko. Competence school for physical education lessons in elementary grades, Scientific magazine of the National pedagogical university of the name of M. P. Dragomanova, Vol. 3K (97), 25-32, 2018. [in Ukrainian].

[11] O. Mozolev, I. Bloshchynskyi, O. Alieksieiev, L. Romanyshyna, L. Zdanevych, I. Melnychuk, K. Prontenko, V. Prontenko, Influence of modern fitness technologies on the state of health and development of motor abilities of 17-19-year-old female students. Journal of Physical Education and Sport, Vol. 19 (Supplement issue 3), Art \# 132 pp. 917 - 924, 2019 Doi: 10.7752 / jpes.2019.s3132

[12] N. M. Goncharova. Attitude of young children of school 
age and their parents to physical activity, Physical culture, sport and health of nation, Vol. 19, No. 1, 110-115, 2015. [in Ukrainian].

[13] S. O. Moiseev. Development key competences for primary students in physical education: challenges and perspectives, Development of vital competence in conditions of educational transformations Vol. 2, 107-111. 2018. [in Ukrainian].

[14] O. Ya. Savchenko. Ability to study is a key competence of junior schoolboy, Kyiv: Pedagogical idea, 2014. [in Ukrainian].

[15] H. Çolak. The Impact of Daily Habits on the Physical Activity Levels of Children Aged 7-10: An Investigation Universal Journal of Educational Research 7(1): 118 - 125, 2019. Doi: 10.13189/ujer.2019.070116

[16] N. Bibik. Competence in primary education outcomes, Initial school, Vol. 9, 1-4, 2010. [in Ukrainian].

[17] I. D. Bekh. Education of personality, Kyiv: Libid, 2008. [in Ukrainian].

[18] H. Acar, N. Eler. The Effect of Balance Exercises on Speed and Agility in Physical Education Lessons. Universal Journal of Educational Research 7(1): 74 - 79, 2019. Doi: 10.13189/ujer.2019.070110

[19] T. Maszczak. Educacja fizyczna w nowej szkole: podrecznik dla studentow wychowania fizycznego, Warszawa: AWF, 2013. [in Polish].

[20] O. Mozolev, M. Khmara, I. Shorobura, I. Bloshchynskyi, K. Prontenko, O. Polishchuk, L. Zdanevych, K. Kruty. Comparative Analysis of the Effectiveness of Polish and Ukrainian Basic Training Programs in Physical Education for 9-10-year-old Pupils, Universal Journal of Educational Research 7(11): 2345-2351, 2019. Doi: 10.13189/ujer.2019.071112

[21] A. Kindzera, I. Bodnar, Ya. Kherbert. Physical activity of the Polish and Ukrainian schoolboys, Physical culture, sport and health of nation Vol. 1, 75-79, 2016. [in Ukrainian].

[22] V. Ivashkovskiy, O. Ostapenko, M. Timchik. Physical education of students of initial classes in extracurricular work of general educational establishments. Kirovohrad: IMEKS-LTD, 2014. [in Ukrainian].

[23] L. Garaschenko. Ways to organize children in physical education: health conservation approach. Preschool education. Vol. 9-10, 12-15, 2013.

[24] T. Krucevich. Development of forms of physical education in general schools: problems and prospects, Scientific magazine of the National pedagogical university of the name of M. P. Dragomanova Vol. 12(67), 75-78, 2015.

[25] M. Malashenko. Ways to implement health education in elementary school, Health Basics, Vol. 2(14) 82-89, 2012.

[26] V. Kashuba, S. Futornyi, O. Andrieieva, N. Goncharova, I. Carp, O. Bondar, N. Nosova. Optimization of the processes of adaptation to the conditions of study at school as a component of health forming activities of primary school-age children. Journal of Physical Education and Sport, Vol 18, Art 377, pp. 2515-2531, 2018 Doi: 10.7752/jpes.2018.04377
[27] O. Kachan, V. Pristinskiy. Informatively communication and mobile cognitive technologies in physical education of children and teenagers, Slovjansk: publishing house B. A. Matorina, 2018. [in Ukrainian].

[28] O. Kachan. Implementation and effective use of the latest information technologies in the process of physical education. Physical education at home school Vol. 3, 33-38, 2016.

[29] O. Mozolev, O. Halus, I. Bloshchynskyi, R. Kovalchuk. Human resources management of educational development in sphere of physical culture and sports in Ukraine: comparative analysis (1992-2016), Journal of Physical Education and Sport, Vol. 19 (Supplement issue 1), Art 28, pp. 185-192, 2019. doi:10.7752/jpes.2019.1028

[30] K. Prontenko, I. Bloshchynskyi, G. Griban, Ye. Zhukovskyi, T. Yavorska, P. Tkachenko, D. Dzenzeliuk, N. Dovgan, S. Bezpaliy, V. Andreychuk Formation of Readiness of Future Physical Culture Teachers for Professional Activity. Universal Journal of Educational Research. 7(9), 1860-1868, 2019. Doi: 10.13189/ujer.2019.070903.

[31] M. Petkova, M. Aleksieva. Factor structure of physical development, physical workability and specific preparedness of 8-year-old school children. Journal of Physical Education and Sport, Vol. 18, Art 309, pp. 2070-2073, doi: 10.7752/jpes.2018.5309

[32] Y. Galan, A. Koshura, Y. Moseychuk, Y. Paliichuk, O. Moroz, O. Tsybanyuk, O. Yarmak. Characteristics of physical conditions of 7-9-year-old schoolchildren within the process of physical education, Journal of Physical Education and Sport, Vol.18, No.5, 1999-2007, 2018. Doi: 10.7752 / jpes. 2018.5297

[33] I. Omelyanenko. About the definition of "program basis" of the system of physical education of schoolchildren. Sportyvnyi visnyk Prydniprovia, Vol. 1, 209-213. 2018. [in Ukrainian].

[34] T. Roters. Methodological principles of physical education of schoolboys, Physical education, sport and culture of health, is in modern society, Vol. 4(20), 180-184, 2012. [in Ukrainian].

[35] S. Marchenko. Terms of effective development of motive capabilities for the schoolboys of junior classes by facilities of mobile games, Physical culture, physical education of different groups of population, Kharkiv: KHDAFK, 2008. [in Ukrainian].

[36] S. Gricyuk. Motor preferences of junior schoolboys as basis of development of motive abilities and skills of junior schoolboys. Actual problems of physical education of different layers of population, Vol.1, 50-56, 2016. [in Ukrainian].

[37] V. Miroshnichenko. Formation of motivation for physical education of young school children, Scientific magazine of the National pedagogical university of the name of M.P. Dragomanova Vol. 3K (97), 345-348, 2018. [in Ukrainian].

[38] O. Andreeva, I. Golovach, I. Khripo. Formation of motivation of primary school students to wellness recreational motor activity, the physical culture, sports and health of the nation, Vol. 1, 11-15, 2016. [in Ukrainian]. 